\title{
ДІАГНОСТИКА ГОТОВНОСТІ ВИКЛАДАЧІВ ЩОДО РОЗВИТКУ ІНФОРМАЦІЙНО-АНАЛІТИЧНОЇ КОМПЕТЕНТНОСТІ МАЙБУТНІХ МЕДИЧНИХ СЕСТЕР
}

\author{
О. Б. Варава \\ ВНЗ «Киӥвський медичний коледж ім. П. І. Гаврося» \\ ДвНЗ «Тернопільський державний медичний університет \\ імені І. Я. Горбачевського МОз Украӥни» \\ ННІ медсестринства
}

У роботі наведено погляди на визначення понять «інформаційно-аналітична компетентність фахівця» та «інформаційно-аналітична компетентність майбутньої медичної сестри», а також результати дослідження готовності викладачів клінічних дисциплін щодо розвитку інформаційно-аналітичної компетентності у студентів медсестринського відділення ВНЗ «Київський Медичний коледж ім. П. І. Гаврося».

\section{ASSESSMENT OF TEACHERS' DEGREE OF READINESS FOR DEVELOPMENT OF THE FUTURE NURSES' INFORMATIONAL AND ANALYTICAL COMPETENCE}

\author{
O. B. Varava \\ P. Havros Kyiv Medical College \\ I. Horbachevsky Ternopil State Medical University \\ Institute of Nursing
}

The article reveals different scientific views concerning the definitions of such concepts as "informational and analytical competence of a specialist" and "informational and analytical competence of the future nurse". The work contains the results of assessment of teachers degree of readiness according to the development of informational and analytical competence of students of Nursing Department of P. Havros Kyiv Medical College.

Вступ. Технічний прогрес у медицині, розширення рамок первинної медико-санітарної допомоги, інформатизація професійного середовища медичної сестри, зростаючий обсяг питань, які потребують іï рішень, високий робочий ритм і брак часу, зміна мотивацій від суто матеріальних цінностей до можливостей самовираження, зумовлюють диференціацію, ускладнення та розширення функцій майбутньої медичної сестри (ММС), зміну їі участі в лікувальнодіагностичному процесі та актуалізують володіння особливими компетентностями, які б забезпечували успішну інформаційно-аналітичну діяльність. Важливість розвитку інформаційно-аналітичної компетентності фахівців медсестринства зумовлена також провадженням ступеневої освіти медичних сестер, поступовим перетворенням медсестринства на окрему доповнювальну, а не повністю підлеглу професію, збільшенням автономії медичної сестри, реалізацією (c) О. Б. Варава, 2018 її права на незалежні медсестринські втручання та вибір тактики ведення пацієнта під час здійснення сестринського процесу, холістичний підхід до вирішення його проблем [1, 2]. У системі медсестринської освіти, де освітньо-кваліфікаційний рівень медичної сестри-магістра - потенційно найбільшого «користувача» цієї компетентності - запроваджено лише $з$ 2008 р. [2], це питання мало вивчене.

Мета роботи: проаналізувати результати дослідження готовності викладачів клінічних дисциплін щодо розвитку інформаційно-аналітичної компетентності у студентів медсестринського відділення ВНЗ «Київський медичний коледж ім. П. І. Гаврося».

Основна частина. Термін «інформаційно-аналітична компетентність» (IAK) тлумачиться неоднозначно. Узагальнено й безвідносно до профілю діяльності, ІАК фахівця - це інтегративна характеристика особистості, яка відображає готовність, здатність і потенціал фахівця за допомогою IKT та на основі семантичної 
обробки інформації ефективно здійснювати інформаційні процеси (визначення інформаційної потреби, пошук, відбір, накопичення, збір, оперативне отримання, оформлення, аналіз, засвоєння, трансформування, обробку, критичне оцінювання, зберігання, передавання, генерування, захист та продуктивне використання інформації) з метою розв'язання професійних завдань за умов швидких змін інформаційного середовища або невизначеності (неповної інформації) [3-6].

Під терміном «ІАK MMC» ми розуміємо інструмент критичної оцінки професійної інформації, що, ґрунтуючись на законах логіки, досвіді та поєднанні інтелектуальних і функціональних здібностей ММС, спроможний за умов недостатньої визначеності (браку інформації і/чи дефіциту часу) забезпечити ухвалення оптимального рішення, прогнозування ситуації та управління проблемою, створення систематизованої цілісної логічної картини світу (проблеми пацієнта) 3 розрізнених інформаційних фрагментів (фактів).

3 метою діагностики готовності викладачів ВНЗ «Київський медичний коледж ім. П. І. Гаврося» щодо розвитку IAK ММС було опитано 42 викладачі професійно-орієнтованих та практичних дисциплін, що викладають на спеціальності 223 «Медсестринство». Методом дослідження обрано анкетування. Для реалізації цього завдання було розроблено анкету із 7 питань, на які викладачам пропонували дати відповіді. На різні питання було передбачено різний формат відповіді:

- обрати за ступенями важливості щодо розвитку IAK певних характеристик та поставити знак «+» В одній із граф: «зовсім не важливо», «не важливо», «важливо», «дуже важливо», «супер важливо» (питання 1, 5);

- обрати з переліку найбільш прийнятні показники щодо розвитку IAK ММС і поставити біля них знак «+» (питання 2, 3, 4, 6, 7).

Питання анкети були сформульовані таким чином, щоб можна було визначити тенденцію, що склалась у діяльності та свідомості викладачів-клініцистів щодо таких параметрів ІАК МMC:

- структура та зміст ІАК ММС (питання 1, 3);

- інтеграція IAK з іншими компетентностями, що входять до складу професійної компетентності ММС (питання 2);

- проекція результатів навчання щодо розвитку IAK MMC на практичну діяльність майбутніх фахівців (питання 4, 6, 7);
- організаційний та операційно-діяльнісний аспект готовності викладачів клінічних дисциплін щодо розвитку IAK у студентів медсестринських відділень (педагогічні технології та методичні прийоми, які респонденти вважають найбільш доцільними для розвитку ІАК ММС) (питання 5).

У результаті проведеного дослідження виявлено такі тенденції:

1. Викладачі коледжу, в цілому, володіють знаннями про структуру ІАК МMC, їі інтеграційні характеристики, значення в професійній діяльності ММС та напрямки розвитку.

2. Найпоширенішою дефініцією, що може бути визначенням IAK MMC, $є$, на думку викладачів, здатність створювати систематизовану цілісну логічну картину світу (проблеми пацієнта) з розрізнених інформаційних фрагментів (фактів), що нам видається досить ємким і точним визначенням IAK саме MMC. Проте поза увагою респондентів залишились такі ключові, на наш погляд, характеристики медсестринської діяльності, як «вміння приймати самостійні обґрунтовані рішення», «здатність прогнозувати ситуацію та контролювати проблему», «вміння робити висновки, застосовуючи закони логіки і досвід» та «критична оцінка професійної інформації».

3. Під час навчальних занять викладачі приділяють більшу увагу технічній роботі з IKT, актуалізують стандартні схеми роботи з пацієнтом, надаючи дещо меншу значущість розвитку мислення студентів та пошуку аргументації думок.

4. Виявлено недостатню увагу викладачів до вміння студентів оновлювати знання та розв'язувати складні практичні завдання і проблеми, які є дієвими способами розвитку аналітичних здібностей майбутніх фахівців медсестринства.

5. Викладачам необхідно звернути увагу на розвиток цінностей та особистісних якостей ММС, що забезпечують високий рівень IAK, зокрема змінити акценти з особистісної якості «поінформованість», яка $є$ тимчасовим станом фахівця через властивість інформації швидко застарівати, на такі цінності та якості, як освіта упродовж життя та уміння швидко вслухатись в суть подій і явищ.

6. Виявлено та потребує корекції дещо звужене розуміння поняття IAK MМС викладачами коледжу: зокрема зовсім не розглядається як один із проявів IAK MMC здатність планувати та управляти часом (тайм-менеджмент), здатність бути критичним і самокритичним, здатність генерувати нові ідеї (креативність), здатність проявляти ініціативу. 
7. Під час освітнього процесу на медсестринських відділеннях увагу переважно акцентують на уміннях ММС правильно зібрати, зафіксувати та передати готову інформацію.

8. Виявлено, що з метою розвитку ІАК ММС викладачі коледжу віддають перевагу методам, що активізують мислення та вимагають від студента креативності, зокрема спілкуванню студента з пацієнтом під час виробничої практики, вирішенню проблемних ситуаційних задач (кейс-метод), роботі в малих групах, організації навчальної практики в ЛПЗ різної форми власності тощо. Чітко простежують усвідомлення непридатності для розвитку IAK репродуктивних та пасивних технологій навчання.

9. Виявлено, що факторами негативної мотивації щодо розвитку ІАК під час навчання в коледжі виступають, в основному, матеріальні причини (низька заробітна плата MC, відсутність механізмів розвитку IAK у лпз через їх недостатнє програмно-комп'ютерне забезпечення) та морально-психологічна неготовність інших учасників лікувально-діагностичного процесу до нової ролі медичної сестри в ньому.

10. 3 боку частини роботодавців і частини викладачів виявлено низьку оцінку інтелектуально-аналітичних здібностей МС, та уявлення про неї як фахівця, нездатного творчо підходити до роботи і проявляти лідерські якості, оскільки найпривабливішими щодо розвитку ІАК уміннями та здатностями випускників під

\section{СПИСОК ЛІТЕРАТУРИ}

1. Новые вызовы организации работы медсестер в сфере первичной медико-санитарной помощи // Головна медична сестра. - 2014. - № 6. - С. 11-16.

2. Махновська І. Р. Професійна підготовка магістрів сестринської справи в умовах ступеневої освіти : автореф. дис. на здобуття наук. ступеня канд. пед. наук : 13.00.04 / Ірина Романівна Махновська. - Житомир, 2015. - 312 с.

3. Петренко Л. М. Теорія і практика розвитку інформаційно-аналітичної компетентності керівників професійно-технічних навчальних закладів : монографія / Л. М. Петренко. - Дніпропетровськ : ІМА-прес, 2013. 456 c.

4. Назначило Е. В. Развитие информационно-аналитической компетентности преподавателя в процессе час працевлаштування $\epsilon$, на думку викладачів, тільки технічні вміння роботи на комп'ютері та в інтернеті.

11. Результати аналізу анкетування слід враховувати при організації та виборі змісту і методів навчання студентів зі спеціальності 223 «Медсестринство». Необхідно організувати роботу психолого-педагогічного та методичного семінарів для викладачів клінічних дисциплін із запрошенням представників практичної охорони здоров'я.

Висновки. IAK $\in$ фундаментальною та інтегративною характеристикою майбутнього фахівця медсестринства, ядром його професійної компетентності та за умов інформатизації суспільства надає конкурентні переваги. Результати діагностики готовності викладачів щодо розвитку інформаційно-аналітичної компетентності майбутніх медичних сестер:

- стали підґрунтям для створення методичних рекомендацій щодо підвищення рівня означеної готовності;

- показали необхідність більшого акценту в педагогічній діяльності на розвитку саме аналітичних здібностей майбутніх фахівців медсестринства, роботи над внутрішнім іміджем ММС та розвитку цінностей та особистісних якостей, що забезпечують високий рівень IAK;

- потребують врахування при організації та виборі змісту і методів навчання студентів, які здійснюють підготовку за навчальним планом спеціальності 223 «Медсестринство».

непрерывного педагогического образования : дисс. ... канд. пед. наук : 13.00.08 / Елена Валерьевна Назначило. - Магнитогорск, 2003. - 193 с.

5. Гайдамак Е. С. Развитие информационно-аналитической компетентности будущего магистра физикоматематического образования : дисс. ... канд. пед. наук : 13.00.02 / Елена Сергеевна Гайдамак. - Омск : РГБ, 2006. - 214 c.

6. Розвиток інформаційно-аналітичної компетентності педагогічних працівників ПТНЗ: теорія і практика : монографія / В. В. Ягупов, Н. О. Величко, І. В. Гириловська [та ін.] ; за наук. ред. В. В. Ягупова. - К : ТОВ «НВП Поліграфсервіс», 2014. - 176 с. 